\title{
Effect of nutritional factors on adherence to antiretroviral therapy among HIV-infected adults: a case control study in Northern Ethiopia
}

\author{
Negassie Berhe ${ }^{1}$, Desalegn Tegabu ${ }^{2}$ and Mekuriaw Alemayehu ${ }^{3^{*}}$
}

\begin{abstract}
Background: Adherence to antiretroviral treatment is critical for suppression of viral replication, reduced destruction of $\mathrm{CD}_{4}$ cells, prevention of viral resistance, promotion of immune reconstitution and slowed disease progression. This study sought to determine the effect of nutritional factors on adherence to ART among HIV-infected adults on ART.

Methods: Matched case control study design (matched by age and sex) was employed. Data was collected from ART registration chart, pre-tested structured data extraction format, anthropometric measurements and by interview. Conditional logistic regression was used to compute the relevant associations among the variables by STATA version 10.

Results: From 174 paired subjects participated in the study 80 (46\%) pair were males and 94 (54\%) pair were females on ART for at least one year prior to the survey. The mean age $( \pm \mathrm{SD})$ for the non-adherent was $38.4 \pm 8.1$ years and for the adherent subjects was $38.5 \pm 8.4$ years. Malnutrition with BMl less than $18.5 \mathrm{Kg} / \mathrm{m}^{2}$ in the adherent group was $14(8 \%)$ and that of the non-adherent group was 74 (42.5\%) which was associated with non-adherence to ART (AOR 10.0,95\%Cl 4.3 - 54.7). Inability to get enough and quality food was also associated with non-adherence to ART (AOR 2.1,95\%Cl $1.1-11.5$ ).

Conclusions: Malnutrition, inability to get enough and/or quality food and consumption pattern which is less than three meals per day were significantly associated with non-adherence to ART. Therefore, the capacity to effectively manage the food and nutrition implications of ART adherence is a critical factor in the success of antiretroviral therapy in resource limited settings.
\end{abstract}

Keywords: HIV/AIDS, Antiretroviral therapy, Nutritional factors, Ethiopia

\section{Background}

The Human Immunodeficiency Virus [HIV] pandemic continues to have a pronounced global impact particularly among the world's resource limited settings [1]. According to Global HIV/AIDS Progress Report of 2011, Globally 34 million people were with HIV at the end of 2010. In sub-Saharan Africa, an estimated 1.9 million people became infected with a total of about 22.6 million in 2010. Access to antiretroviral therapy in low and middle income countries increased to 6.65 million in 2010,

\footnotetext{
* Correspondence: mekugeorg@gmail.com

${ }^{3}$ Department of Environmental and Occupational Health and Safety, Institute of Public Health, College of Medicine and Health Sciences, University of Gondar, Gondar, Ethiopia

Full list of author information is available at the end of the article
}

$47 \%$ coverage of people eligible for treatment. SubSaharan Africa had the greatest increase in the number of people receiving antiretroviral therapy to about 5 million in 2010 [1]. In Ethiopia in 2011 adult HIV prevalence was $1.5 \%$ [2]. By the end of 2011, a total of 333,434 people had ever started ART. Of those there were 249,174 adults currently on treatment [3].

Adherence to antiretroviral treatment is defined as taking $95 \%$ or more of the prescribed doses on time and in the correct way, either with or without food [4]. It is critical for suppression of viral replication, reduced destruction of CD4 cells, prevention of viral resistance, promotion of immune reconstitution, and slowed disease progression [5,6]. However, from those who are on Antiretroviral Therapy [ART], around one out of four

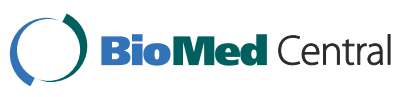


ART users fail to achieve optimal adherence due to different reasons like nutritional, social and economic conditions [7]. HIV-positive individuals especially those on ART are prone to malnutrition due to inadequate dietary intake, appetite loss, nutritional losses, metabolic changes, and increased requirements for both macroand micro-nutrients [8].

Combating under-nutrition and HIV/AIDS are two of the eight United Nations Millennium Development Goals to be achieved by 2015. HIV infection is a global public health emergency and is most prevalent in areas of the world where under-nutrition is also a serious concern [8]. Lack of food security and poor nutritional status may hasten progression to AIDS-related illnesses, undermine adherence and response to antiretroviral therapy and exacerbate socioeconomic impacts of the virus [4]. To prevent such problems high-income countries and international organizations like World Food Program [WFP], World Health Organization [WHO], President's Emergency Plan for AIDS Relief [PEPFAR], Food and Agriculture Organization [FAO] and United States Agency for International Development [USAID] recommend nutritional support as a part of the care provided to HIVpositive individuals $[4,8,9]$.

In developing countries chronic underlying malnutrition and its intersection with food insecurity, poverty, and co-infections pose a serious threat to efforts to combat HIV/AIDS [10]. Adults living with HIV have 10-30\% higher energy requirements than a healthy adult without HIV [4]. High prevalence of HIV, non adherence to antiretroviral [ARV] drugs and malnutrition results in a vicious cycle of under nutrition, poverty, and disease progression [10]. In Ethiopia, approximately $49 \%$ of the general population is without adequate nutrition [11]. In addition to this, according to two studies in Ethiopia (Dire Dawa and Jimma zone southwest Ethiopia) the prevalence of food insecurity among People Living with HIV/AIDS [PLHIV] on ART were 90\% and 63\% respectively $[12,13]$ which indicates adults on ART are suffering from malnutrition.

There are documented evidences which recommend detailed studies on the impact of nutritional factors on adherence to ART [12,14,15]. The effect of nutritional factors on adherence to ART among HIV/AIDS subjects is not well explored, despite the critical role of nutrition in care, disease progression and ART adherence among HIV/AIDS cases. Therefore, the objective of this study is to assess the effect of nutritional factors on adherence to antiretroviral therapy among HIV-infected adults in Tigray region north Ethiopia. The findings of this study could be useful evidence for scholars who are interested in this field, and for the ART and nutrition programs undertaking by government and other non-governmental organizations.

\section{Methods}

The study employed matched case control study design for clients under ART. For the comparison purpose, non-adherent subjects were matched by age and sex with adherent controls.

The study was conducted in four hospitals found in Tigray Regional state. Tigray regional state which is found in north Ethiopia has an estimated total population of $4,314,456$ according to Central Statistical Authority [CSA] report in 2007 [16]. It has five zonal Administrative Divisions and there are about 1.8\% PLHIV [2], among these about 28,044 are on ART. Tigray Regional state has 14 hospitals and 219 health centers [17]. The ART patients taking treatment and care in ART clinics of the hospitals included in the study are Mekelle hospital 3645, Adwa hospital 876, St. Marry hospital 942 and Suhul hospital 1098. The study period was from August 5/2012 to October $17 / 2012$.

The study population was adult HIV/AIDS positive subjects greater than 18 years who were in ART follow up in four Hospitals of Tigray regional state. Participants with incomplete data for last three visits and women on ART who were on current pregnancy were excluded from the study. Non-adherent participants from document who were adherent in the current visit, and adherent participants with good adherence from document and who were non-adherent at current visit were also excluded.

The sample size is computed by Kelsey formula for case control studies in OpenEpi Version 3.03.17 assuming a ratio of non-adherent cases to adherent controls of 1:1, a two-sided significance level (alpha) of 0.05 , Power $80 \%$ and assuming $15 \%$ difference in nutritional status between the adherent and non-adherent subjects. In a case control study done in Pwani Region eastern Tanzania, the difference between the two groups in educational status, income, occupation and other socioeconomic factors which also are included in our study is less than $12 \%$ [18]. However, considering the cost and the design of the study the $15 \%$ difference assumption was taken for calculating the sample size. By considering this the sample size calculated for both groups was 171 pair. With adjustment for non-response (5\%), the sample size for both groups' was 180 pair.

From the governmental hospitals found in the Tigray regional state, four hospitals were selected purposely considering the load and the availability of FluorescenceActivated Cell Sorting [FACS] Count Machine for $\mathrm{CD}_{4}$ count and $\mathrm{CBC}$ (complete blood count) machines for the purpose of getting an adequate number of nonadherent subjects with better documentation within the given shorter period of data collection. By scanning patient ART follow up charts we selected patients who were non-adherent (poor and fair) at least once in the 
last three visits for follow up appointment. From the selected non-adherent HIV-infected clients, those who reported having ingested less than $95 \%$ of the total number of the prescribed antiretroviral medication for the last one month were considered as "cases". Age and sex matched adherent controls that were with good adherence in all of the last three visits and those who reported having ingested $95 \%$ or more of the total number of the prescribed antiretroviral medication for the last one month was considered as "controls". Finally data was collected for the matched pair by collecting first the non-adherent cases and then the adherent controls for each case (106 from Mekelle hospital, 28 from Suhul hospital, 21 from St. Marry hospital and 19 from Adwa hospital), until the matched sample size make up the whole sample of 174 .

The primary dependent variable was Adherence to ART and other independent variables were defined as a categorical variable with the following:-

Adherence to ART: - is defined as taking one's medicine as prescribed and agreed between the patient and provider which is $95 \%$ or more adherence to ART. Which means taking doses no more than two hours before or two hours after the time of a doctor's advice to take doses $(95 \%$ or more adherence $=$ missing $\leq 2$ doses of 30 doses or $\leq 3$ doses of 60 doses) [11,19]. Non-adherence to ART: - is the condition of missing doses completely, not following information given by a physician, as well as taking drugs inappropriately. Which means taking doses two or more hours before, and/or two or more hours after the time of a doctor's advice to take doses or missing doses completely (less than $95 \%$ adherence $=$ missing $>2$ doses of 30 doses or $>3$ doses of 60 doses) [11,19].

PHQ-9 score for depression (points): - A score of 1 to 4 No depression, 5 to 9 - Mild depression, 10 to 14 Moderate depression, 15 to 19 - Moderately Severe depression and 20 to 27 - Severe depression [20]. Altitude adjusted hemoglobin:- the adjustment is subtracted from each individual's observed hemoglobin level to calculate an adjusted hemoglobin. The altitude of Adwa, Shire, Mekelle and Axum is 1882, 1953, 2084 and 2195 meter respectively from sea level which is found in the range $1750 \leq \mathrm{m}<2250$ which will be adjusted by subtracting $0.8 \mathrm{~g} / \mathrm{dl}$ from the observed hemoglobin [21].

Functional Status: -

- Working actively: Able to perform usual work in or out of the house.

- Ambulatory: Able to perform activities of daily living.

- Bedridden: Not able to perform activities of daily living [22].
Table 1 Socio-demographic and economic characteristics of the study participants comparing adherent and nonadherent in Tigray regional state, northern Ethiopia, 2012

\begin{tabular}{|c|c|c|}
\hline \multirow{2}{*}{$\begin{array}{l}\text { Characteristics of study } \\
\text { participants }\end{array}$} & \multicolumn{2}{|c|}{ Status of adherence to ART } \\
\hline & $\begin{array}{l}\text { Non-adherent to ART } \\
\text { number (\%) }\end{array}$ & $\begin{array}{l}\text { Adherent to ART } \\
\text { number (\%) }\end{array}$ \\
\hline \multicolumn{3}{|l|}{ Sex } \\
\hline Male & $80(46)$ & $80(46)$ \\
\hline Female & $94(54)$ & $94(54)$ \\
\hline \multicolumn{3}{|l|}{ Age } \\
\hline $18-29$ & $23(13.2)$ & $23(13.2)$ \\
\hline $30-39$ & $72(41.4)$ & $71(40.8)$ \\
\hline $40-49$ & $67(38.5)$ & $66(38)$ \\
\hline$\geq 50$ & $12(6.9)$ & $14(8)$ \\
\hline \multicolumn{3}{|l|}{ Permanent address } \\
\hline Urban & $156(89.7)$ & 159(91.4) \\
\hline Rural & $18(10.3)$ & $15(8.6)$ \\
\hline \multicolumn{3}{|l|}{ Marital Status } \\
\hline Single & $38(21.8)$ & 39(22.4) \\
\hline Married & $67(38.5)$ & $76(43.7)$ \\
\hline Widowed & $38(21.8)$ & $43(24.7)$ \\
\hline Divorced & $31(17.9)$ & $16(9.2)$ \\
\hline \multicolumn{3}{|l|}{ Educational status } \\
\hline No education & $31(17.8)$ & $37(21.3)$ \\
\hline Elementary (1 - 8) & $94(54)$ & $58((33.3)$ \\
\hline Secondary (9 - 12) & $38(21.8)$ & $49(28.2)$ \\
\hline $12+$ & $11(6.4)$ & $30(17.2)$ \\
\hline \multicolumn{3}{|l|}{ Occupation } \\
\hline Have no Job & 26(14.9) & $44(25.3)$ \\
\hline Government employed & $42(24.2)$ & $46(26.4)$ \\
\hline Self employed/business & 54(31) & $36(20.7)$ \\
\hline Daily laborer & $52(29.9)$ & $48(27.6)$ \\
\hline \multicolumn{3}{|l|}{ Living With } \\
\hline Alone & $67(38.5)$ & $52(29.9)$ \\
\hline Family & $81(46.6)$ & $84(48.3)$ \\
\hline Parents & $9(5.1)$ & $9(5.1)$ \\
\hline With others & $17(9.8)$ & $29(16.7)$ \\
\hline \multicolumn{3}{|l|}{$\begin{array}{l}\text { Average Monthly income } \\
\text { (Ethio. Birr) }\end{array}$} \\
\hline No income & $25(14.4)$ & 26(14.9) \\
\hline$\leq 500$ & $95(54.6)$ & 65(37.4) \\
\hline $501-999$ & 24(13.8) & $31(17.8)$ \\
\hline$\geq 1000$ & $30(17.2)$ & $52(29.9)$ \\
\hline \multicolumn{3}{|l|}{ Distance to hospital (Km) } \\
\hline$\leq 10$ & $112(64.4)$ & $130(74.7)$ \\
\hline$>10$ & $62(35.6)$ & 44(25.3) \\
\hline
\end{tabular}


In all investigations, the measurement was completed as follows. Height was measured to the nearest 1 centimeter using a portable, free - standing stadiometer. Weight was measured to the nearest $0.01 \mathrm{~kg}$ using ward or clinical based clinical scales, all of which were calibrated at the start of the study. We were rate good appetite for those study participants who eats full of the plate and/or most of plate and we were rate poor appetite for those study participants who eats half of the plate and less. We have collected data on adequate and/or quality food by using questions of eating pattern and nutritional factors. We were rate adequate for those study participants who get three or more meals per day with and without eating between meals.

Data on demographic factors, nutritional factors, immuno-hematological factors and self report adherence to ART were collected by document review, anthropometric measurements, and by using a structured pre-tested questionnaire which is developed from different literatures. The structured questionnaire was prepared in English version and translated to Tigrigna, and again back to English to confirm the correctness of the translation, efficiency of questionnaire and for analysis purpose. It had detailed questions on predictor factors like socio-demographic characteristics, psychosocial factors, nutritional factors and ART self reported adherence. Interview was conducted to fill the structured questionnaire in their own respective ART clinics after being oriented as to how to do it by trained data collectors and supervisors. The data collectors were 4 case managers, 4 nurses or health officers and 4 MSc students as supervisors.

After coding the data was entered using Excel, data cleanup and cross-checking was done and it was analyzed by using STATA version 10 by principal investigator using conditional logistic regression (clogit) model for matched case control analysis. The association of each variable with non-adherence was tested using the odds ratio, the 95\% confidence interval and p value; a p-value less than 0.05 being considered statistically significant.

Ethical clearance was obtained from University of Gondar research and publication office and then the ethical clearance was submitted to Tigray Regional Health Bureau. Official letters given from Tigray Regional Health Bureau was submitted to the respective hospital administration Chief Executive Officers and Medical Directors to get formal permission. The purposes and importance of the study was explained and informed consent was secured from each participant. Confidentiality was maintained at the data collection process and data analysis stages. All of the study participants were assured that the data will be anonymous, names or any personal identifiers will not be recorded and that was done according to the agreement. Participant's involvement in the study was on voluntary basis and those who wish to quit their participation at any stage were informed to do so without any restriction.

\section{Results}

A total of 174 subjects were participated in the present study, of which $80(46 \%)$ pair were males and 94 (54\%) pair were females on ART for at least one year prior to the survey. The mean age $( \pm \mathrm{SD})$ was $38.4 \pm 8.1$ years for the non-adherent and $38.5 \pm 8.4$ years for adherent subjects. Of the participants 71 (40.8\%) from the adherent group and $72(41.4 \%)$ from the non-adherent group belongs to the age group $30-39$ years (Table 1 ).

Among the study participants 76 (43.7\%) from the adherent group and 67 (38.5\%) from the non- adherent group were married while 39 (22.4\%) from the adherent

Table 2 The trend of clinical \& nutritional status among study participants comparing adherent \& non-adherent subjects using mean at each visit in Tigray regional state, northern Ethiopia, 2012

\begin{tabular}{|c|c|c|c|c|c|c|}
\hline $\begin{array}{l}\text { Characteristics of study } \\
\text { participants }\end{array}$ & $\begin{array}{l}\text { Status of adherence } \\
\text { to ART }\end{array}$ & $\begin{array}{l}\text { At initiation } \\
\text { of ART }\end{array}$ & $\begin{array}{l}\text { 1st visit of last } \\
\text { three visits }\end{array}$ & $\begin{array}{l}\text { 2nd visit of last } \\
\text { three visits }\end{array}$ & $\begin{array}{l}\text { 3rd visit of last } \\
\text { three visits }\end{array}$ & $\begin{array}{l}\text { Current } \\
\text { visit }\end{array}$ \\
\hline \multirow[t]{2}{*}{ BMI (Kg/m2) } & Adherent & 18.5 & 20.2 & 20.7 & 21.0 & 21.5 \\
\hline & Non-adherent & 17.9 & 19.1 & 19.3 & 19.1 & 19.1 \\
\hline \multirow[t]{2}{*}{ Weight (Kg) } & Adherent & 50.8 & 55.5 & 56.8 & 57.5 & 59.1 \\
\hline & Non-adherent & 48.1 & 51.5 & 51.8 & 51.4 & 51.3 \\
\hline Observed HGB & Adherent & 12.2 & 13.8 & 14.2 & 14.5 & 14.5 \\
\hline$(\mathrm{mg} / \mathrm{dl})$ & Non-adherent & 12.3 & 13.3 & 13.6 & 13.8 & 13.8 \\
\hline Adjusted HGB by & Adherent & 11.4 & 13.0 & 13.4 & 13.7 & 13.7 \\
\hline altitude (mg/dl) & Non-adherent & 11.5 & 12.5 & 12.8 & 13.0 & 13.0 \\
\hline \multirow[t]{2}{*}{ TLC $\left(10^{6}\right.$ cells $\left./ \mathrm{mm}^{3}\right)$} & Adherent & 5.5 & 5.6 & 5.6 & 5.7 & 5.6 \\
\hline & Non-adherent & 5.3 & 5.4 & 5.6 & 5.6 & 5.7 \\
\hline \multirow[t]{2}{*}{ CD4 (cells $/ \mathrm{mm}^{3}$ ) } & Adherent & 155 & 408 & 460 & 495 & 522 \\
\hline & Non-adherent & 140 & 282 & 302 & 324 & 304 \\
\hline
\end{tabular}

N.B:- BMI, Body Mass Index; HGB, Hemoglobin; TLC, Total Leukocyte Count; CD4=Cluster of Differentiation 4. 
group and 38 (21.8\%) from the non-adherent group were never married. Assessment of educational status of the study participants showed that $79(45.4 \%)$ from the adherent group and 59 (39.6\%) from the non-adherent group attended secondary school or higher education (Table 1).

In the assessment of the average monthly income of the study participants 91 (52.3\%) from the adherent group and 120 (69\%) from the non-adherent group had monthly income below 27 \$ or 500 Ethiopian Birr. From the study participants $84(48.3 \%)$ from the adherent group and 81 (46.6\%) from the non-adherent group live with their families. The majority of the study participants; 159 (91.4\%) from the adherent group and 156 (89.7\%) from the non-adherent group were from urban (Table 1).

At initiation of ART close to 135 (77.6\%) from the adherent group and 135 (77.6\%) from the non-adherent group had $\mathrm{CD}_{4}$ count of less than 200 cells $/ \mathrm{mm}^{3}$. Eighty seven (50\%) participants from the adherent group and 105 (60.3\%) from non-adherent group had a BMI less than $18.5 \mathrm{Kg} / \mathrm{m}^{2}$. The body mass index of the adherent subjects was increased by a mean of $0.4 \mathrm{Kg} / \mathrm{m}^{2}$ in the latest four visits (within the last two years). However; there was no mean increment in BMI in the non-adherent participants (Table 2). The mean increment in weight of the adherent group in the latest four visits was $1.2 \mathrm{Kg}$ but the weight in the non-adherent group was decreased by a mean of $0.1 \mathrm{Kg}$ (Table 2). The mean increment in altitude adjusted hemoglobin in the non-adherent participants was $0.4 \mathrm{mg} / \mathrm{dl}$ and that of the adherent group was increased by $0.6 \mathrm{mg} / \mathrm{dl}$. In addition to this, the mean $\mathrm{CD}_{4}$ count of the adherent participants was increased by a mean of 38 cells and that of the non-adherent participants was increased by a mean of 8 cells (Table 2 ).

Among the study subjects 123 (70.7\%) from adherent group and 113 (64.9\%) from non-adherent respondents reported that they are satisfied with ART benefit they obtained. From the non-adherent group 21 (12\%) and from the adherent group $1(0.6 \%)$ had moderately severe and severe depression ( $\geq 15$ points). In the last three months $22(12.7 \%)$ from the non-adherent group and 6 (3.4\%) from the adherent group were ambulatory in their functional status (Table 3).

In the bivariate analysis adjusted mean HGB of latest four visits, mean total leukocyte count (TLC) of the latest four visits, ever use of alcohol after starting ART, current alcohol use (within 30 days), and PHQ-9 score for depression are significantly associated with non-adherence to ART (Table 4).

The multivariate analysis was used to identify characteristics that were predictive of non-adherence to ART. Mean BMI of the latest four visits less than $18.5 \mathrm{Kg} / \mathrm{m}^{2}$, unable to get enough and/or quality food, consumption
Table 3 Psychosocial and health service related factors among study participants comparing adherent and non-adherent using a Chi-Square test in Tigray regional state, northern Ethiopia, 2012

\begin{tabular}{|c|c|c|c|}
\hline \multirow{2}{*}{$\begin{array}{c}\text { Characteristics of study } \\
\text { participants }\end{array}$} & \multicolumn{2}{|c|}{ Status of adherence to ART } & \multirow[t]{2}{*}{ P-value } \\
\hline & $\begin{array}{l}\text { Non-adherent to } \\
\text { ART Number (\%) }\end{array}$ & $\begin{array}{l}\text { Adherent to ART } \\
\text { Number (\%) }\end{array}$ & \\
\hline $\begin{array}{c}\text { Current cigarette smoking } \\
\text { (within } 30 \text { days) }\end{array}$ & & & 0.431 \\
\hline Yes & $16(9.2)$ & $12(6.9)$ & \\
\hline No & 158(90.8) & 162(93.1) & \\
\hline $\begin{array}{c}\text { Ever cigarette smoking after } \\
\text { starting ART }\end{array}$ & & & 0.855 \\
\hline Yes & $16(9.2)$ & 17(9.8) & \\
\hline No & 158(90.8) & 157(90.2) & \\
\hline $\begin{array}{c}\text { Ever khat chewing after } \\
\text { starting ART }\end{array}$ & & & 0.149 \\
\hline Yes & $21(12.1)$ & $13(7.5)$ & \\
\hline No & 153(87.9) & $161(92.5)$ & \\
\hline Disclosure of ART use & & & 0.659 \\
\hline Yes & $148(85.1)$ & 145(83.3) & \\
\hline No & $26(14.9)$ & $29(16.7)$ & \\
\hline Family support for ART use & & & 0.411 \\
\hline Yes & $117(75.5)$ & $116(79.5)$ & \\
\hline No & $38(24.5)$ & $30(20.5)$ & \\
\hline Satisfaction by ART benefit & & & 0.251 \\
\hline Yes & $113(64.9)$ & $123(70.7)$ & \\
\hline No & $61(35.1)$ & $51(29.3)$ & \\
\hline $\begin{array}{l}\text { PHQ-9 score for depression } \\
\text { (points) }\end{array}$ & & & 0.000 \\
\hline $0-4$ & $53(30.5)$ & $115(66.1)$ & \\
\hline $5-9$ & $72(41.4)$ & $50(28.7)$ & \\
\hline $10-14$ & $28(16.1)$ & $8(4.6)$ & \\
\hline $15-27$ & $21(12)$ & $1(0.6)$ & \\
\hline $\begin{array}{l}\text { Functional status in last } \\
\qquad 3 \text { months }\end{array}$ & & & 0.006 \\
\hline Working actively & $152(87.3)$ & 168(96.6) & \\
\hline Ambulatory & $22(12.7)$ & $6(3.4)$ & \\
\hline
\end{tabular}

pattern of last 24 hours and mean $\mathrm{CD}_{4}$ count of the latest four visits less than 350 cells $/ \mathrm{mm}^{3}$ are independently associated factors with non-adherence to ART (Table 5).

\section{Discussion}

This study focused on determining the effect of nutritional factors on adherence to ART among adult people living with HIV taking antiretroviral therapy. As a result, abnormality in nutritional factors, dietary patterns and immuno-hematological status were found significantly associated with non-adherence to ART. This is in line 
Table 4 Bivariate associations of the levels of adherence to ART with behavioral, clinical, food \& diet related factors among study participants in Tigray regional state, northern Ethiopia, 2012

\begin{tabular}{|c|c|c|c|}
\hline \multirow[t]{2}{*}{ Characteristics of study participants } & \multicolumn{2}{|c|}{ Status of adherence to ART } & \multirow[t]{2}{*}{ COR $(95 \% \mathrm{Cl})$} \\
\hline & Non-adherent to ART Number (\%) & Adherent to ART Number (\%) & \\
\hline \multicolumn{4}{|l|}{ Daily eating pattern of last 12 months } \\
\hline Three meals \& above & $21(12.1)$ & $17(9.8)$ & 1 \\
\hline Two meals \& eating between meals & 136(78.2) & $140(80.5)$ & $0.8(0.4-1.6)$ \\
\hline Two meals or less & 17(9.8) & $17(9.8)$ & $0.8(0.3-2.3)$ \\
\hline \multicolumn{4}{|l|}{ Source of food in the last 12 months } \\
\hline Purchase (market/grocery) & 148(85.1) & 144(82.8) & 1 \\
\hline Household farm/garden & $11(6.3)$ & 15(8.6) & $0.7(0.3-1.6)$ \\
\hline Support from others & 15(8.6) & 15(8.6) & $0.9(0.4-2.2)$ \\
\hline \multicolumn{4}{|c|}{ Adjusted mean HGB of the latest four visits (mg/dl) } \\
\hline$<11.5$ & $29(16.7)$ & $3(1.7)$ & $14(3.3-58.8)$ \\
\hline$\geq 11.5$ & 145(83.3) & 171(98.3) & 1 \\
\hline \multicolumn{4}{|c|}{ Mean TLC of the latest four visits $\left(10^{6} \mathrm{cell} / \mathrm{s} / \mathrm{mm}^{3}\right)$} \\
\hline$<4.0$ & $28(16.1)$ & $11(6.3)$ & $2.7(1.3-5.60$ \\
\hline$\geq 4.0$ & 146(83.9) & 163(93.7) & 1 \\
\hline \multicolumn{4}{|l|}{ Occupation } \\
\hline - Have no Job & 26(14.9) & $44(25.3)$ & 1 \\
\hline - Government employed & $42(24.1)$ & $46(26.4)$ & $1.6(0.8-3.2)$ \\
\hline - Self employed/business & $54(31)$ & $36(20.7)$ & $2.7(1.3-5.3)$ \\
\hline - Daily laborer & $52(29.9)$ & 48(27.6) & $1.8(1.0-3.4)$ \\
\hline \multicolumn{4}{|l|}{ Duration of treatment (months) } \\
\hline $12-36$ & $33(19)$ & 28(16.1) & 1 \\
\hline $37-60$ & $72(41.4)$ & $93(53.5)$ & $0.6(0.4-1.2)$ \\
\hline$\geq 61$ & 69(39.6) & $53(30.4)$ & $1.1(0.6-2.0)$ \\
\hline \multicolumn{4}{|l|}{ Current alcohol consumption (within 30 days) } \\
\hline Yes & $73(42)$ & $11(6.3)$ & $13.4(5.4-33.2)$ \\
\hline No & $101(58)$ & 163(93.7) & 1 \\
\hline \multicolumn{4}{|l|}{ Ever use of alcohol after starting ART } \\
\hline Yes & 140(80.5) & $89(51.1)$ & $4.9(2.7-8.9)$ \\
\hline No & $34(19.5)$ & $85(48.9)$ & 1 \\
\hline \multicolumn{4}{|l|}{ PHQ-9 score for depression (Points) } \\
\hline$<5$ & $53(30.5)$ & 115(66.1) & 1 \\
\hline$\geq 5$ & $121(69.5)$ & 59(33.9) & $5.1(3.0-8.9)$ \\
\hline \multicolumn{4}{|l|}{ Current khat chewing (within 30 days) } \\
\hline Yes & $17(9.8)$ & $7(4)$ & $2.4(1.0-5.9)$ \\
\hline No & 157(90.2) & 167(96) & 1 \\
\hline
\end{tabular}

N.B:- TLC, Total Leukocyte Count; HGB, Hemoglobin; NGO, Non-Government Organization; PHQ, Patient Health Questionnaire.

with other studies which reported nutritional factors may have an effect on adherence to ART [12,14]. In addition to this, there are few emerging articles which recommend detailed studies on the effect of nutritional factors and dietary patterns of adherence to ART as these may have an effect on adherence to ART $[12,14,15]$.
As to this study result, malnutrition (which is defined as $\mathrm{BMI}<18.5 \mathrm{Kg} / \mathrm{m}^{2}$ ) was significantly associated with non-adherence to ART. Malnutrition was about 10 times more frequent in the non-adherent participants than in the adherent counterparts. This is in line with a quasiexperimental study in Zambia [14], and a study from 
Table 5 Multivariate associations of the levels of adherence to ART among study participants in Tigray regional state, northern Ethiopia, 2012

\begin{tabular}{|c|c|c|c|c|}
\hline \multirow[t]{2}{*}{ Characteristics of study participants } & \multicolumn{2}{|c|}{ Status of adherence to ART } & \multirow[t]{2}{*}{ COR $(95 \% \mathrm{Cl})$} & \multirow[t]{2}{*}{ AOR $(95 \% \mathrm{Cl})$} \\
\hline & Nonadherent $\backslash$ to ART Number (\%) & Adherent to ART Number (\%) & & \\
\hline \multicolumn{5}{|l|}{ Mean BMI of latest four visits $\left(\mathrm{Kg} / \mathrm{m}^{2}\right)$} \\
\hline$<18.5$ & $74(42.5)$ & 14(8) & $7.7(3.8-15.4)$ & $10.0(4.3-54.7)$ \\
\hline$\geq 18.5$ & $100(57.5)$ & $160(92)$ & r & r \\
\hline \multicolumn{5}{|l|}{ Unable to get enough and/or quality food } \\
\hline Yes & 119(68.4) & $80(46)$ & $2.6(1.6-4.2)$ & $2.1(1.1-11.5)$ \\
\hline No & 55(31.6) & $94(54)$ & r & r \\
\hline \multicolumn{5}{|l|}{ Consumption pattern of last 24 hours } \\
\hline Three meals $\&$ above & 124(71.3) & 163(93.7) & r & r \\
\hline Less than three meals & $50(28.7)$ & $11(6.3)$ & $8.8(3.5-22.2)$ & $10.9(1.3-81.4)$ \\
\hline \multicolumn{5}{|l|}{$\begin{array}{l}\text { Mean } \mathrm{CD}_{4} \text { count of latest four visits } \\
\text { (cells } / \mathrm{mm}^{3} \text { ) }\end{array}$} \\
\hline$<350$ & 118(67.8) & $25(15.5)$ & $8.6(4.7-15.6)$ & $18.3(6.7-102.7)$ \\
\hline$\geq 350$ & $56(32.2)$ & $147(84.5)$ & r & r \\
\hline \multicolumn{5}{|l|}{ Appétit in last 7 days } \\
\hline Good & $89(51.1)$ & 135(77.6) & r & r \\
\hline Poor & $85(48.9)$ & $39(22.4)$ & $3.6(2.1-6.0)$ & $2.0(0.7-6.0)$ \\
\hline \multicolumn{5}{|l|}{ I could not afford to eat balanced meals } \\
\hline Yes & 160(92) & 136(78.1) & $2.7(1.5-5.0)$ & $2.0(0.5-11.9)$ \\
\hline No & $14(8)$ & 38(21.9) & r & r \\
\hline \multicolumn{5}{|l|}{ Education } \\
\hline No education & $31(17.8)$ & $37(21.3)$ & $4.5(2.0-10.3)$ & $5.6(0.7-42.9)$ \\
\hline Elementary (1 - 8) & $94(54)$ & $58(33.3)$ & $2.3(1.0-5.6)$ & $1.9(0.2-14.9)$ \\
\hline Secondary $(9-12)$ & $38(21.8)$ & $49(28.2)$ & $2.6(1.1-6.2)$ & $0.6(0.1-4.2)$ \\
\hline $12+$ & $11(6.4)$ & $30(17.2)$ & r & r \\
\hline \multicolumn{5}{|l|}{ Average Monthly income (Ethio. Birr) } \\
\hline - no income & $25(14.4)$ & 26(14.9) & $2.6(1.4-4.6)$ & $1.4(0.4-5.9)$ \\
\hline$\cdot \leq 500$ & $94(54)$ & $65(37.4)$ & $1.3(0.6-2.6)$ & $1.0(0.2-6.6)$ \\
\hline • 501-999 & 24(13.8) & $31(17.8)$ & $1.7(0.8-3.6)$ & $3.0(0.6-19.1)$ \\
\hline$\cdot \geq 1000$ & $31(17.8)$ & $52(29.9)$ & r & $r$ \\
\hline \multicolumn{5}{|l|}{ Distance to hospital (Km) } \\
\hline$\leq 10$ & $112(64.4)$ & 130(74.7) & r & r \\
\hline$>10$ & $62(35.6)$ & $44(25.3)$ & $1.6(1.0-2.6)$ & $1.9(0.8-10.3)$ \\
\hline
\end{tabular}

N.B:- $B M I$, Body Mass Index; $C D_{4}$, Cluster of Differentiation 4. r:- reference.

Uganda [15] which reported that better nutritional status could enhance adherence to ART. However, this is not in line with the cross sectional study in Dire Dawa Ethiopia which reported nutritional status had no impact on adherence to ART [12]. This study reported that people with good nutritional status miss doses more than those with poor nutritional status [12]. The possible explanation for this difference may be because of the difference in design of the studies. A randomized clinical trial among wasted adult people living with HIV who receives supplementary food for 14 weeks and not, in Blantyre, Malawi also reported that no differences were seen in ART adherence [23]. The reason for this may be because of the shorter time of supplementation to have an effect on adherence to ART.

In this study, the inability to get enough and/or quality food was about 2.1 times higher in the non-adherent group which shows a significant association with nonadherence to ART. In other studies, increasing and integrating nutritional supplementation which improves 
access to food into ART programs improve adherence and maximize the benefits of ART therapy [14,24]. In the qualitative study from Uganda, South Africa, Tanzania, and Malawi, hunger during HAART initiation emerged as a leading obstacle to ARV adherence [7]. In addition to this, other studies revealed that lack of food as the main challenge to ART adherence [25-27]. The prospective observational study from central Haiti also found that providing food assistance to individuals with HIV and those under food insecurity improves BMI, food security and adherence to clinic visits [28]. This all shows nutritional factors have effects on adherence to ART.

The consumption pattern which is less than three regular meals per day of last 24 hours was significantly associated with non-adherence to ART. In addition to this, poor appetite and unable to afford balanced meals were associated with non-adherence to ART in the bivariate analysis which is supported by the qualitative study from Uganda [6]. In another qualitative study in northeastern Uganda, consuming only one meal per day and being dependent on caregivers for food were risk factors for ARV non-adherence [29]. In addition to this, in Zambia, the belief that ARVs must be taken with food led individuals to skip doses when they could not access enough to eat [30]. The study from Jimma zone south west Ethiopia reported that food insecurity was high among HAART treated people living with HIV/AIDS even though not showing its effect on adherence. That study reported that significant numbers of PLHIV took less than the mean eating occasions and food diversity [13].

In the multivariate analysis of this study the participants with a mean CD4 count of the latest four visits less than 350 cells $/ \mathrm{mm}^{3}$ was associated with nonadherence to ART compared to the adherent counterpart. In the study of Nutrition for Healthy Living Cohort (NFHL), lower $\mathrm{CD}^{+}$cell counts were associated with lower weight. Each 100 -cell $/ \mathrm{mm}^{3}$ decrease in $\mathrm{CD}^{+}$cell count was associated with a $1.9 \mathrm{~kg}$ lower weight [31]. In a study from West Africa average BMI and CD4 cell count was 20.7 and $20.5,217$ and $191 / \mathrm{mm}^{3}$ respectively, an increase in CD4 cell count was around 1.7 times higher $\left(+114\right.$ vs. $+68 \mathrm{CD}_{4}$ cells $/ \mathrm{mm}^{3}$ respectively in support and control groups [32] which shows nutritional status may have an effect on treatment outcomes of HIV/AIDS.

In addition to the negative consequences of personal, socioeconomic and provider related factors on day-to-day ARV adherence in other studies, our study elucidated that malnutrition and dietary factors are risk factors for ART non-adherence, which have been shown to be associated with virologic failure, worse clinical outcomes and mortality in another randomized trial of west African adults [33]. In the pilot intervention study in Zambia, individuals receiving food supplementation with HAART achieved significantly higher ARV adherence than individuals not receiving food supplementation [14]. Another study from Uganda also concluded that malnutrition and food insecurity have emerged as major barriers to the effectiveness of ART programs including adherence to ART [15] which is in line with our study's result.

The findings of this study should be interpreted with some limitations. Our case control study provides statistical associations of effects of nutritional factors on adherence to ART. This cannot establish whether poor nutrition is a cause or a consequence of non-adherence to ART. In addition to this, the study relies on participants' selection and the data collected from documents filed by different professionals including Health officers, BSc nurses, and Diploma graduated nurses at the different sites of the study area. The reason for this is the four hospitals have different professionals at their ART clinics. Apart from this the selection of non-adherent subjects may have some limitations. These subjects were selected by combining previous and current adherence level criteria to avoid selection bias. However, for the sake of different reasons the non-adherent subjects may be nutritionally affected ones. In addition to this self report of historical events (recall bias) could have been present. Moreover, the use of ART clinic nurses and ART case managers in the hospitals as data collectors might have introduced an interviewer bias.

\section{Conclusions}

Despite the limitations of our study, through construction of a plausible control group and rigorous analysis of collected data, our finding has elucidated the presence of positive associations of malnutrition and other dietary factors on adherence to ART. In this study malnutrition at least mild malnutrition, lack of food and consumption pattern which is less than three meals per day were significantly associated with non-adherence to ART.

\section{Competing interest}

The authors declare that they have no competing interest.

\section{Authors' contributions}

NB wrote the proposal of this research. DT, MA revised the proposal and incorporate some comments. NB, DT, MA participated in data collection and analysis. MA wrote the final manuscript. All authors read and approved the final manuscript.

\section{Acknowledgement}

The authors wish to thank the study participants for their contribution to the research, as well as to Tigray Regional Health Bureau for their cooperation, permission of the ethical clearance and preparing letters to the respective hospital administrations. The authors specifically like to thank Elsa Hagos for her support during the translation of the structured questionnaire to Tigrigna. This paper is made possible by the support of American people through the United States Agency for International Development (USAID). 


\section{Author details}

${ }^{1}$ Department of Public Health Officer, Health Science College, Axum University, Axum, Ethiopia. 'Department of Health Informatics, Institute of Public Health, College of Medicine and Health Science, University of Gondar Gondar, Ethiopia. ${ }^{3}$ Department of Environmental and Occupational Health and Safety, Institute of Public Health, College of Medicine and Health Sciences, University of Gondar, Gondar, Ethiopia.

Received: 30 January 2013 Accepted: 22 May 2013

Published: 23 May 2013

\section{References}

1. WHO, UNICEF, UNAIDS, GLOBALHIV/AIDSRESPONSE: Epidemic update and health sector progress towards Universal Access. 2011.

2. Central Statistical Agency: Ethiopia Demographic and Health Survey 2011. 2012. http://www.csa.gov.et/

3. Federal HIV/AIDS Prevention and Control Office (HAPCO): Ethiopia Country Progress Report on HIV/AIDS Response, 2012. Addis Ababa, Ethiopia; 2012.

4. United Stated Agency for International Development (UNAIDS): HIV, Food Security and Nutrition; UNAIDS Policy Brief. 2008.

5. Steel G, Nwokike J, Joshi MP: Development of a Multi-Method Tool to Measure ART Adherence in Resource-Constrained Settings: The South Africa Experience. RPM Plus. 2007

6. Weiser SD, Tuller DM, Frongillo EA, Senkungu J, Mukiibi N, Bangsberg DR: Food insecurity as a barrier to sustained antiretroviral therapy adherence in Uganda. PLoS One 2010, 5(4):e10340.

7. Hardon AP, Akurut D, Comoro C, Ekezie C, Irunde HF, Gerrits T, et al: Hunger, waiting time and transport costs: Time to confront challenges to ART adherence in Africa. AIDS Care 2007, 19(5):658-665.

8. Louise C, Ivers LC, Cullen KA, Freedberg KA, Block S, Coates J, Webb P: HIV/AIDS, Undernutrition and Food Insecurity. Clin Infect Dis 2009, 49(7):1096-1102.

9. Mills E, Nachega JB, Buchan I, Orbinski J, Attaran A, Singh S, et al: Adherence to Antiretroviral Therapy in Sub-Saharan Africa and North America. JAMA 2006 296(6):679-690.

10. Talam NC, Gatongi $P$, Rotich J, Kimaiyo S: Factors affecting antiretroviral drug adherence among HIV/AIDS adult patients attending HIV/AIDS clinic at Moi Teaching and Referral Hospital, Eldoret, Kenya. East Afr J Public Health 2008, 5(2):74-78.

11. Ethiopian Federal Ministry Of Health (FMOH): National Guidelines for HIVI AIDS and Nutrition. 2008. http://www.pronutrition.org/.

12. Abiy S: Impact of Food and Nutrition Security on Adherence to Anti-Retroviral Therapy (ART) and Treatment Outcomes among Adult PLWHA in Dire Dawa Provisional Administration. Addis Ababa University [Internet]. 2007. Available from: http://hdl.handle.net/123456789/861.

13. Tiyou A, Belachew T, Alemseged F, Biadgilign S: Food Insecurity and Associated Factors among HIV-infected individuals receiving highly active antiretroviral therapy in Jimma zone. Southwest Ethiop Nutr J 2012 11:51

14. Cantrell RA, Sinkala M, Megazinni K, Lawson-Marriott S, Washington S, Chi BH, et al: A Pilot Study of Food Supplementation to Improve Adherence to Antiretroviral Therapy Among Food-Insecure Adults in Lusaka, Zambia. JAIDS J Acquir Immune Defic Syndr 2008, 49(2):190-195. Oct.

15. Rawat R, Kadiyala S, McNamara PE: The impact of food assistance on weight gain and disease progression among HIV-infected individuals accessing AIDS care and treatment services in Uganda. BMC Publ Health 2010, 10:316. Jun 7.

16. Ethiopian Central Statistical Authority (CSA): Ethiopian National Central Statistics Agency report. Addis Ababa, Ethiopia; 2007. http://www.csa.gov.et/.

17. Tigray Regional Health Bureau: Tigray Regional Health Bureau First quarter report of 2004 E.C, 2012: Mekelle. In. Mekelle. 2012.

18. Idindili B, Jullu B, Mugusi F, Tanner M: A case-control study of factors associated with non-adherent to antiretroviral therapy among HIV infected people in Pwani Region, eastern Tanzania. Tanzan J Health Res 2012, 14(3):1-12

19. Amico KR, Simoni J, Wilson I, Malow RM, Devieux J, Deschamps A: Monitoring Patient Adherence: Recommendations from and for Practice. 2009.

20. Kroenke K, Spitzer R, Williams J: The PHQ-9: Validity of a brief depression severity measure. J Gen Intern Med 2001, 16:606-613.

21. Sullivan K: Determining an Individual's Anemia Status based on Hemoglobin Levels. 2001.
22. Eyuel T, Worku A: Assessment of antiretroviral treatment outcome in public hospitals, South Nations Nationalities and Peoples Region, Ethiopia. Ethiop J Health Dev 2011, 25(2):102-109.

23. Manary M, Ndekhat $M$, vanOosterhout J: Supplementary feeding in the care of the wasted HIV infected patient. Malawi Med J 2010, 22(2):46-48. Jun.

24. Byron $\mathrm{E}$, Gillespie $\mathrm{S}$, Nangami M: Integrating nutrition security with treatment of people living with HIV: lessons from Kenya. Food Nutr Bull 2008, 29(2):87-97. Jun

25. Lyimo R, de Bruin M, van den Boogaard J, Hospers H, van der Ven A, Mushi D: Determinants of antiretroviral therapy adherence in northern Tanzania: a comprehensive picture from the patient perspective. BMC Publ Health 2012, 12:716. Aug 30.

26. Senkomago V, Guwatudde D, Breda M, Khoshnood K: Barriers to antiretroviral adherence in HIV-positive patients receiving free medication in Kayunga, Uganda. AIDS Care 2011, 23(10):1246-1253. Oct

27. Nyanzi-Wakholi B, Lara A, Munderi P, Gilks C, Dart Trial Team: The charms and challenges of antiretroviral therapy in Uganda: the DART experience. AIDS Care 2012, 24(2):137-142.

28. Ivers LC, Chang Y, Gregory Jerome J, FreedbergK A: Food assistance is associated with improved body mass index, food security and attendance at clinic in an HIV program in central Haiti: a prospective observational cohort study. AIDS Res Ther 2010, 7:33. Aug 26

29. Peter O, Andrew K, Curtis C, Will S, Aranka A, Edward M: Adherence to antiretroviral therapy among a conflict-affected population in Northeastern Uganda: a qualitative study. AIDS 2008, 22:1882-1884.

30. Sanjobo N, Frich JC, Fretheim A: Barriers and facilitators to patients' adherence to antiretroviral treatment in Zambia: a qualitative study. SAHARA J 2008, 5(3):136-143.

31. Mangili A, Murman DH, Zampini AM, Wanke CA, MayerK H: Nutrition and HIV Infection: Review of Weight Loss and Wasting in the Era of Highly Active Antiretroviral Therapy from the Nutrition for Healthy Living Cohort. Clin Infect Dis 2006, 42(6):836-842

32. Serrano C, Laporte R, Ide M, Nouhou Y, Truchis P, Rouveix E, et al: Family nutritional support improves survival, immune restoration and adherence in HIV patients receiving ART in developing country. Asia Pac J Clin Nutr 2010, 19(1):68-75.

33. Danel C, Moh R, Chaix M-L, Gabillard D, Gnokoro J, Diby C-J, et al: Two-Monthsoff F-M-oARItRoR, Compared with Continuous Therapy: A Randomized Trial Involving West African Adults. J Infect Dis. 2009 Jan 1;199(1):66-76.: TwoMonths-off, Four-Months-on Antiretroviral Regimen Increases the Risk of Resistance, Compared with Continuous Therapy: A Randomized Trial Involving West African Adults. J Infect Dis 2009, 199(1):66-76. Jan 1.

doi:10.1186/1471-2334-13-233

Cite this article as: Berhe et al.: Effect of nutritional factors on

adherence to antiretroviral therapy among HIV-infected adults: a case control study in Northern Ethiopia. BMC Infectious Diseases 2013 13:233.

\section{Submit your next manuscript to BioMed Central and take full advantage of:}

- Convenient online submission

- Thorough peer review

- No space constraints or color figure charges

- Immediate publication on acceptance

- Inclusion in PubMed, CAS, Scopus and Google Scholar

- Research which is freely available for redistribution 